\title{
МЕТОДОЛОГІЧНІ ЗАСАДИ ПІЗНАННЯ КІБЕРНЕТИЧНОЇ БЕЗПЕКИ
}

Веселова Л. Ю.

У науковій статті розглядається питання методологічних засад пізнання кібернетичної безпеки. Акцентується увага на тому, що напрацювання у сфері інформаційноі безпеки нададуть можливість більш результативнішого та дієвого аналізу кібербезпеки, що у свою чергу згенерує масив знань для формування обгрунтованої та ефективноі державної політики щодо протидії кібернетичним загрозам. Проаналізовано концептуальні підходи відомих учених щодо формування методологічних засад дослідження феномену кібернетичної безпеки.

Ключові слова: інформаційна безпека, гібридні загрози, кібернетичний простір, інформаційні явища.

В научной статье рассматривается вопрос методологических основ познания кибернетической безопасности. Акцентируется внимание на том, что наработки в сфере информационной безопасности предоставят возможность более результативного и эффективного анализа кибербезопасности, что в свою очередь генерирует массив знаний для формирования обоснованной и эффективной государственной политики по противодействию кибернетическим угрозам. Проанализированы концептуальные подходы известных ученых по формированию методологических основ исследования феномена кибернетической безопасности.

Ключевые слова: информационная безопасность, гибридные угрозы, кибернетическое пространство, информационные явления.

The article deals with the methodological principles of cyber security knowledge. It is said that the problem of security in general, information and cybernetics, in particular, has been extremely urgent in recent decades and is spreading so rapidly that it is somehow impossible to focus on the new phenomenon essence and the limits of its use in legal support context. Therefore, there is a need to clarify and further delve into the essence of understanding cyber security through retrospective analysis of information security to modern cybersecurity principles based on the assets of the most prominent representatives of scientific opinion in this field. Attention is drawn to the fact that developments in the field of information security will enable a more effective and efficient analysis of cybersecurity, which in turn generates an array of knowledge to formulate a valid and effective government policy to counteracting cyber threats. The article deals with the conceptual approaches to considering the information security problem of the leading representatives of German existentialism, the scientists' research on the peculiarities of providing information security in the system of political and political-legal relations in determining the state-legal policy of providing information security in social transformations. Besides, the article deals with the well-known scientists' research who dealt with issues related to developing directions for counteracting hybrid threats. Summarizing the approaches and directions for forming the methodological foundations of cyber security phenomenon study, the author, relying, of course, on, in a certain way, generic links with information security, notes that the branch of security studies, interdisciplinary links, relevance and intensity, etc., form an extremely

Веселова Л. Ю., 2019 important aspect of the methodological framework - complexity, versatility and social inclusiveness of cybersecurity. It is also concluded that the development of information space and informative-telecommunication technologies, their impact on reality, diversity of information phenomena and processes, which are, first and foremost, peculiar and special in nature, still require a universal and integrated approach, since interconnected with various spheres of public relations.

Key words: information security, hybrid threats, cyber space, information phenomena.

Постановка проблеми та ї̈ актуальність. Такі процеси, як швидкий розвиток інформаційно-телекомунікаційних технологій, часткове перенесення комунікаційних відносин суспільства в кіберпростір потребують системного осмислення політики в кібернетичній сфері, що неможливо без дослідження методологічних засад пізнання кібернетичної безпеки.

Аналіз останніх досліджень і публікацій. Специфічні питання, пов'язані з протидією кібернетичним загрозам, сьогодні набули великої актуальності та перебувають у центрі суспільної уваги. Вагомий науковий внесок у дослідження вказаної проблеми в зазначеній сфері зробили відомі вчені: О.А. Баранов, В.М. Семенов, О.О. Гиркін, М.М. Безкоровайний, В.М. Бутузов, О.Є. Користін, Д.Й. Никифорчук, Ю.Ю. Орлов, Ю.М. Оніщенко, А.Л. Татузов, О.О. Черноног та інші науковці. Разом із тим тема щодо методологічних засад пізнання кібернетичної безпеки не здобула достатнього висвітлення в працях науковців.

Метою статті $\epsilon$ спроба системно охарактеризувати методологічні засади пізнання кібернетичної безпеки.

Виклад основного матеріалу. Характеризуючи концептуальні підходи до розуміння феномену «кібернетична безпека», вітчизняні й зарубіжні вчені надзвичайно ґрунтовно та всебічно визначають предмет наукового пошуку та формують відповідну методологічну базу.

Стан кібернетичної безпеки сьогодні привертає увагу вчених самого широкого спектру гуманітарного та технічного напрямів. Міждисциплінарний характер кібернетичної безпеки як проблеми і предмета наукового пізнання зумовлює залежність від неї значного спектру та сегментів суспільних відносин.

Зазначене зумовило предметну сферу, певним чином споріднену з досить широким спектром соціально-гуманітарних досліджень трансформації явищ соціальної, правової й державної дійсності, які перебувають під значним впливом тенденцій стрімкого інформаційного розвитку, а отже, у прямій залежності від інформаційної безпеки [1, с. 7].

Інформаційний та кібернетичний простори займають значне місце в економічному та соціальному розвитку країн світу. В Україні існує ціла низка проблем вразливості інформаційної сфери відносно стороннього кібернетичного впливу. Протистояти фізичному руйнуванню технічних засобів, порушенню функціонування 
об'єктів нападу та протиправній діяльності соціальних інженерів із дня на день стає все важче через недостатнє кадрове забезпечення відповідними фахівцями у сфері інформаційної та кібербезпеки. Необхідним $\epsilon$ створення умов для безпечного функціонування кіберпростору, його використання в інтересах особи, суспільства і держави [2].

Проблема безпеки взагалі інформаційної та кібернетичної зокрема останніми десятиліттями $\epsilon$ надзвичайно актуальною й поширюється настільки швидко, що певним чином неможливо зосередитись на сутності нового явища та межах його використання в контексті правового забезпечення. Тому виникає необхідність конкретизувати та більш глибоко розкрити сутність розуміння проблеми кібернетичної безпеки через ретроспективний аналіз інформаційної безпеки до сучасних безпекознавчих засад кібербезпеки на основі надбань найбільш відомих представників наукової думки в цій сфері. Разом із тим напрацювання у сфері інформаційної безпеки нададуть можливість більш результативнішого та дієвого аналізу кібербезпеки, що у свою чергу згенерує масив знань для формування обґрунтованої та ефективної державної політики щодо протидії кібернетичним загрозам.

Визначення підходів щодо формування філософських засад безпеки пов'язується 3 епохою Відродження. Людиноцентристський підхід, на якому базувалася думка мислителів того часу, зосереджував увагу на духовному житті людини та звільненні ії від соціальної несправедливості. Удосконалення зброї, створення численних армій і воєнних коаліцій, багаторічні війни, що продовжували «роздирати» європейські країни, змусили мислителів епохи Відродження задуматися над проблемою безпечних стосунків між державами і шукати шляхи їх нормалізації, зокрема через обмін інформацією з проблем безпеки [3, с. 20].

Розпочинаючи з XVII ст., 3'являються підходи щодо правового врегулювання міжнародних відносин. Одним із засновників теорії природного права й науки міжнародного права був голландський мислитель Гроцій Гуго де Гроот. Його трактат «Про право війни і миру» присвячений насамперед проблемам міжнародного права. Г. Гроцій пропонував заснувати орган для розв'язування суперечок між державами, який би мав ефективні (у тому числі інформаційні) засоби примусу $[4$, c. $145-147]$.

У XVII ст., коли завершується становлення більшості національних держав Європи, окреслився етап обґрунтування ідеї «вічного миру», зокрема у працях «Політичний заповіт» А.-Ж. Рішельє, «Досліди» Ф. Бекона та ін. [3, с. 21].

Певне наукове бачення щодо розуміння та напрямів забезпечення національної безпеки, їі інформаційної складової, що за своєю суттю відповідає сучасним підходам, займало місце в поглядах мислителів Т. Гоббса та Е. Канта. Як справедливо зазначає український дослідник проблем безпеки О. Дзьобань, погляди Т. Гоббса й Е. Канта на сутність досліджуваної проблеми найбільш характерні в цьому контексті. Розуміючи під природним станом стан беззаконня й наявності у кожного права на все, Еммануїл Кант та Томас Гоббс зауважують на необхідності встановлення громадянського устрою, в якому забезпечувалася би безпека індивіда [5, с. 81].
Незважаючи на принципові розбіжності в поглядах обох філософів на процесуальні аспекти досягнення безпечного стану, ці теорії збігаються у тому, що споконвічно притаманна індивідам повна свобода ними (теоріями) обмежується заради безпеки в усіх аспектах іiі розуміння, але безпека дає змогу цю волю здійснити. Судження цих мислителів стосовно кола проблем безпеки продовжують виконувати значущу роль в усвідомленні того, де ми знаходимося і куди маємо рухатися у пошуку правильного шляху до майбутнього безпечного існування. У сучасних умовах пошуку оптимальних варіантів стосовно вирішення проблеми забезпечення безпеки індивідів, суспільств, держав та їхніх союзів, органічне поєднання раціональних зерен обох наведених теорій, безумовно, сприятиме відшуканню того оптимального стану й способу забезпечення інформаційної та кібернетичної безпеки, який буде прийнятним для різних суспільних утворень у теперішньому багатополюсному світі [3, с. 22].

їхні фундаментальні ідеї щодо основних підходів у реалізації безпечного стану життєдіяльності людини, суспільства та держави, щодо елементів забезпечення миру й безпеки, без сумніву, $\epsilon$ досить актуальними в сучасних умовах процесу активної розбудови світового співтовариства щодо превалювання, еталонного визнання й певної змістовної стандартизації ідей доктрини права, свободи та рівності.

3-поміж іншого, філософська й політична активність Дж. Локка відображала погляди щодо безпеки у ранньому Просвітництві. А розроблення філософських проблем безпеки через релігійно-етичне розуміння проблеми миру здійснювали в цю ж епоху Ф. Вольтер, Д. Дідро. Гоббсівську точку зору підтримував Ж.-Ж. Руссо [6, с. 160].

Чимало цікавих ідей щодо вирішення проблем безпеки запропонували соціалісти-утопісти Клод Анрі де Ревруа Сен-Сімон, Шарль Фур'є і Роберт Оуен. Зокрема, Р. Оуен вважав, що забезпечити якісно новий безпечний стан - вселюдську гармонію - може лише належним чином організоване виховання людей на основі ефективного використання інформаційних аспектів виховного процесу. Вчений підкреслював, що тільки звільнення народів від приватновласницької кабали і об'єднання їх в один союз зупинить насильство й уможливить забезпечення безпеки [7, с. 81].

Питання безпеки особливої актуальності набувають у другій половині XX сторіччя у зв'язку з поширенням ядерного озброєння й розумінням глобальної загрози масового знищення. Узагальнюючи філософські ідеї мислителів XX сторіччя щодо безпеки та їі інформаційного (кібернетичного) складника, передусім необхідно виділити Р. Арона, А. Бергсона, М.Л. Кінга, Б. Рассела, П.Т. де Шардена, А. Тойнбі, А. Швейцера, К. Ясперса та ін. Французький філософ Анрі Бергсон, поєднуючи інформаційну безпеку з розумінням закритого й відкритого суспільств, указував, що насильство й війни $\epsilon$ неминучим наслідком закритих суспільств i, отже, сумною необхідністю епохи [8, с. 103].

Концептуальні підходи до розгляду проблеми інформаційної безпеки пропонував один із провідних представників німецького екзистенціалізму Карл Ясперс. Екзистенційна філософія Ясперса в цьому розрізі ґрунтується на розумінні безпеки людини, яка (безпека) безпосередньо поєднується з інформацією про світ [9, с. 39-40]. 
Філософію ненасильства впродовж усього життя сповідував видатний американський мислитель і громадський діяч Мартін Лютер Кінг. У праці «Шлях до свободи» він сформулював шість основних принципів ненасильства, кожен з яких безпосередньо чи опосередковано містить інформаційний аспект [10, с. 66].

Світові глобалізаційні процеси й розвиток інформаційного суспільства значним чином зумовлюють та не можуть залишити осторонь увагу сучасних науковців і дослідників щодо проблем інформаційної та кібернетичної безпеки. Очевидним також $\epsilon$ те, що сучасні методологічні засади філософського осмислення феномену кібернетичної безпеки не можуть не враховувати надбання історико-філософської спадщини, що і закладає методологічні засади сприйняття та подальшого дослідження проблематики кібернетичної безпеки в умовах швидкоплинного світу. Зокрема, цільовим проблемам інформаційної безпеки присвячено праці вітчизняних науковців: В. Брижко, Л. Задорожної, В. Гавловського, М. Гуцалюка, Р. Калюжного, А. Марущака, В. Цимбалюка, В. Шамрая, М. Швеця, В. Шкарупи, Ю. Яцишина та інших.

Поряд із тим багатогалузевий характер прояву інформаційного середовища i, відповідно, розгалуженість напрямів забезпечення інформаційної (кібернетичної) безпеки спрямували науковий пошук за межі юридичних наук. Так, філософськими та соціологічними аспектами забезпечення інформаційної безпеки в контексті осмислення соціокультурного феномену, проблем безпеки соціуму загалом, сучасних суспільних перетворень, а також соціального конфлікту займалися Я.С. Артамонова, Є.О. Архипова, Г.А. Атаманов, М.Ю. Захаров, В.Ю. Триняк, О.М. Циденова, В.П. Шемякін та інші.

Особливості забезпечення інформаційної безпеки у системі політичних і політико-правових відносин щодо визначення державно-правової політики забезпечення інформаційної безпеки в умовах соціальних трансформацій знайшли своє відображення в дослідженнях широкої низки науковців, серед яких: М.О. Богданова, О.Ю. Борисов, М.І. Бусленко, І.І. Залєвська, В.О. Козубський, В.К. Конах, О.О. Левін, О.О. Ніколаєв, ІО. Пеньков, О.А. Судоргін та інші.

У контексті забезпечення інформаційної та кібернетичної безпеки в Україні набули великої актуальності та перебувають у центрі суспільної уваги питання, пов'язані з протидією гібридним загрозам. В останні роки у багатьох наукових роботах значна увага приділяється саме окремим проблемам протидії гібридним загрозам в України. Зокрема, питання, пов'язані з розробкою напрямів щодо протидії гібридним загрозам, ставали предметом досліджень багатьох відомих учених: Р. Арзуманяна, 3. Гбур, Є. Магди, М. Мальського, В. Мартинюка, В. Предборського, І. Руснака та інших $[11$, с. $70 ; 12$, с. 165$]$.

Окремої уваги потребують складники методології дослідження адміністративно-правового забезпечення кібернетичної безпеки, що визначаються як унікальними властивостями предмету дослідження у правовому та соціальному контекстах, так і теоретико-правовою формою його осмислення і відображення, світогляд- ними, філософськими й наукознавчими підвалинами науки XXI сторіччя, новітньою науковою картиною світу права, тенденціями його розвитку тощо [13 с. 248-249]. щоправда, мають місце різні підходи щодо структури методології дослідження в системі юридичних наук.

Таким чином, ґенеза наукової думки щодо забезпечення кібернетичної безпеки, інформаційної безпеки та безпеки загалом у межах адміністративно-правового дослідження дозволяє виділити, перш за все, методологічні засади на базі загальнотеоретичних підходів: світоглядних, філософських, наукознавчих, соціологічних тощо:

сучасні світоглядні підходи, що сформувалися в епоху розвитку інформаційного суспільства, базуються на ключових ідеях майбутнього розвитку людства - інформатизації та комп'ютеризації суспільства, що об'єктивно приходить на зміну матеріальному виробництву, а також на ідеї глобалізації інформаційного суспільства тощо;

- філософські засади знайшли своє осмислення впродовж довгого історичного розвитку філософської думки та з-поміж загалу, заслуговують на увагу філософські підходи, розроблені в працях Ю. Хабермаса [14; 15], Г.-Г. Гадамера $[16 ; 17 ; 18]$, М. Гайдеггера $[19 ; 20 ; 21$; 22; 23; 24] та інших філософів;

наукознавчі засади сформовані у контексті інтеграції об'єктивного й суб'єктивного в осмисленні реалій кібернетичної безпеки, міждисциплінарності і проблемності дослідження, спрямованості на усвідомлення процесів глобалізації, регіоналізації, конвергенції сучасного інформаційного та правового просторів [25], а також специфічної наукова картина світу як єдності й диференціації матеріального та віртуального [26];

соціологічні засади сформовані у контексті концептуалізації постіндустріального, інформаційного та громадянського суспільства, з урахуванням теорії глобалізації й катастроф, які закладають основні теоретичні орієнтири дослідження проблем забезпечення кібернетичної безпеки як складного, багатовимірного та універсального соціального феномену, на основі взаємодії державних і недержавних інституцій, правового та іншого соціального регулювання.

Висновки. Узагальнюючи підходи та напрями щодо формування методологічних засад дослідження феномену кібернетичної безпеки, спираючись, звісно, на, певним чином, родові зв'язки з інформаційною безпекою, зазначимо, що розгалуженість безпекознавчих наукових досліджень, міждисциплінарні зв'язки, актуальність та інтенсивність тощо формують надзвичайно важливий аспект методологічного базису - комплексність, багатогранність та соціальну всеосяжність забезпечення кібербезпеки. Розвиток інформаційного простору та інформаційно-телекомунікаційних технологій, їхній вплив на реальність, різноманітність інформаційних явищ та процесів, що $\epsilon$ насамперед своєрідними й особливими за своєю природою, все ж потребують універсального та комплексного підходу, оскільки взаємопов'язані з різноманітними сферами суспільних відносин. 


\section{Література}

1. Тихомиров 0.0. Забезпечення інформаційної безпеки як функція сучасної держави : моногр. ; заг. ред. Р.А. Калюжний. Київ : Центр навч.-наук. та наук.-практ. вид. НА СБ України, 2014. 196 с.

2. Інформаційна та кібербезпека: соціотехнічний аспект : підручник / В.Л. Бурячок та ін. ; за заг. ред. д-ра техн. наук, професора В.Б. Толубка. Київ : ДУТ, 2015. 288 с.

3. Березовська І.Р. Адміністративно-правові засоби забезпечення інформаційної безпеки в Україні : дис. ... кандидата юридичних наук : 12.00.07. Київ, 2012. 239 с.

4. Гроций Гуго. О праве войны и мира: Три книги, в которых объясняются естественное право и право народов, а также принципы публичного права ; А.Л. Саккетти (пер.). Москва : Ладомир, 1994. 868 с.

5. Дзьобань О.П. Національна безпека України: концептуальні засади та світоглядний сенс : монографія. Харків : Майдан, 2007. 284 с.

6. Трактаты о вечном мире / предисл. чл.-кор. АН СССР Ф.В. Константинова ; вводная статья и примеч. И.С. Андреевой. Москва : Соцэкгиз, 1963. 278 с.

7. Очирова О.А. Проблемы социального развития в контексте эволюции природы труда. Вестник Московского университета. 2009. № 4. С. 80-89.

8. Бергсон А., Мунье Э., Мерло-Понти М. Французская философия и эстетика XX века. Сборник ; предисл. П. Мореля. Москва : Искусство, 1995. 269 с.

9. Хайдеггер М., Ясперс К. Переписка, 1920-1963 ; пер. с нем. И. Михайлов. Москва : Ad Marginem, 2001. 415 с.

10. Кинг Мартин Лютер. Любите врагов ваших. Bonpoсы философии. 1992. № 3. С. 66-71.

11. Ковальчук Т.І., Користін О.Є., Свиридюк Н.П. Гібридні загрози у секторі цивільної безпеки в Україні. Наука і правоохоронна. 2019. № 3 (45). С. 69-79.

12. Kovalchuk T.I., Korystin O.Y., Sviridyuk N.P. Hybrid threats in the civil security sector in Ukraine. Проблеми законності. 2019. Вип. 147. С. 163-175.

13. Тихомиров А.Д. Юридическая компаративистика: философские, теоретические и методологические проблемы. Киев : Знання, 2005. 334 с.

14. Токарська А.С. Правова комунікація в контексті посткласичного праворозуміння : автореф. дис. ... докт. юрид. наук : спец. 12.00.12 «Філософія права». Київ, 2008. 35 с.

15. Яременко І.А. Комунікативне вчення Юргена Хабермаса в проблемному полі незавершеності модерну : автореф. дис. ... канд. юрид. наук : спец. 09.00.05 «Історія філософії». Донецьк, 2007. 17 с.
Правове забезпечення адміністративної реформи

16. Бернюков А.М. Юридична герменевтика як методологія здійснення правосуддя (філософсько-теоретичний аналіз) : автореф. дис. ... канд. юрид. наук : спец. 12.00.12 «Філософія права». Львів, 2008. 16 с.

17. Дудаш Т.І. Праворозуміння: герменевтичне дослідження : автореф. дис. ... канд. юрид. наук : спец. 12.00.01 «Теорія та історія держави і права; історія політичних і правових учень». Львів, 2008. 16 с.

18. Тодика Ю.М. Тлумачення Конституції і законів України: теорія та практика : монографія. Харків : Факт, 2003. 322 c.

19. Єзеров А.А. Конституційний конфлікт як феномен та процес в Україні : автореф. дис. ... канд. юрид. наук : спец. 12.00.02 «Конституційне право; муніципальне право». Одеса, 2007. 18 с.

20. Заінчковський М.Л. Права людини як новоєвропейський філософський та політико-правовий феномен : автореф. дис. ... канд. юрид. наук : спец. 12.00.12 «Філософія права». Київ, 2003. 20 с.

21. Колпаков В.К. Деліктний феномен в адміністративному праві України : автореф. дис. ... докт. юрид. наук : спец. 12.00.07 «Адміністративне право і процес; фінансове право; інформаційне право». Київ, 2005. 37 с.

22. Левчук-Хмара М.В. Право в сучасному етикофілософському дискурсі : автореф. дис. ... канд. філософ. наук : 09.00.07 «Етика». Київ, 2010. 15 с.

23. Лемак В.В. Правова реформа в Чехії і Словаччині в умовах постсоціалістичної модернізації: теоретичні і практичні проблеми : автореф. дис. ... докт. юрид. наук : спец. 12.00.01 «Теорія та історія держави і права; історія політичних і правових учень». Харків, 2003. 40 с.

24. Триняк В.Ю. Інформаційна безпека як соціокультурний феномен (соціально-філософський аналіз) : автореф. дис. ... канд. філософ. наук : спец. 09.00.03 «Соціальна філософія та філософія історії». Донецьк, 2009. 19 с.

25. Воротилина Т.Л. Постнеклассические тенденции в западной и российской традициях правопонимания : дис. ... канд. юрид. наук : 12.00.01. Нижний Новгород, 2002. 228 C.

26. Иванов С.И. Виртуальность. Москва, 2006. 187 с.

Веселова Л. Ю., orcid.org/0000-0001-6665-0426 кандидат юридичних наук,

доцент кафедри адміністративної діяльності поліції одеського державного університету внутрішніх справ 